\title{
The Relationship Between Financial Efficacy, Satisfaction With Remuneration And Personal Financial Well-Being
}

Wilmie Vosloo, North-West University, Potchefstroom, South Africa Jaco Fouché, North-West University, Potchefstroom, South Africa Jaco Barnard, North-West University, Potchefstroom, South Africa

\begin{abstract}
Financial stress is a condition that is becoming more prevalent in today's society due to factors such as high debt levels, low savings and economic recessions. Research has found that financial stress negatively influences employees' performance at work. With these increasing pressures on personal finances and its interference on work, this study considers whether management should attempt to improve employees' financial well-being. Management needs to be convinced that their actions can improve their employees' financial well-being. This study established and measured the relationship that the subjective measures financial efficacy and satisfaction with remuneration have on financial well-being. A sample size of 9057 employees from different sectors in South Africa was used. Confirmatory factor analyses were used, as the survey was based on a previously developed survey and it was already known which items load onto which factors. Data was analysed using Pearson correlation coefficients and multiple regression analysis. Three hypotheses were tested. Hypothesis 1: There is a relationship between satisfaction with remuneration and financial well-being. Hypothesis 2: There is a relationship between financial well-being and financial efficacy. Hypothesis 3: Financial efficacy moderates the relationship between satisfaction with remuneration and financial well-being. The results from this study supported all three hypotheses. Personal financial efficacy and satisfaction with remuneration were found to have a strong positive relationship with financial well-being. The study also established that the relationship between remuneration satisfaction and financial well-being was stronger in people with higher financial efficacy. It is argued that management can intervene with employees' financial well-being by improving financial efficacy through financial education and by improving their satisfaction with remuneration. Satisfaction with remuneration can be increased by increasing actual remuneration and benefits, addressing administrative issues of the pay system, addressing staff morale or by increasing financial efficacy. Staff with higher wellbeing will contribute to the better performance of the entity.
\end{abstract}

Keywords: Financial Well-Being; Financial Efficacy; Personal Finance; Remuneration Satisfaction

\section{INTRODUCTION}

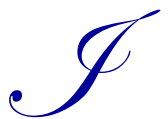

$n$ recent times, financial literacy has gained the attention of a wide range of interested parties, such as major banking companies, government agencies, grass-root consumers and community interest groups (Louw, Fouché, \& Oberholzer, 2013). Linked to a lack of financial literacy is financial stress, a condition that is experienced by society with increasing frequency (Kim, Garman, \& Sorhaindo, 2003; Garman, Leech, \& Grable, 1996; Garman et al., 2004). The ongoing current worldwide recession, worries about inadequate savings, consumerism and debt accumulation are all contributing to the increase in financial stress. The current economic downturn caused the financial pressures of households to increase (Kim \& Garman, 2004; Weller \& Logan, 2009). According to Molitor (2010), Americans are still stressed about their financial situation even if it appears that the economy is recovering, indicating that there are other factors that also contribute to financial stress. 
People know they should save, but they do not save. People need to save $15 \%$ of their disposable income for 30 years in order to receive $50 \%$ of their current salary during retirement (Dutkiewicz, Levin, \& Dukhi, 2007). A savings ratio below this $15 \%$ is likely to increase the pressure on the current and future financial situation. German households saved 10\% (Trading Economics, 2013a) of their disposable income, whereas American households only saved between 4.5 and 5.2\% (Trading Economics, 2013b) during the third quarter of 2013. The saving situation appears even more grim in South Africa, where households saved $-0.02 \%$ of their disposable income in the second quarter of 2013 (South African Reserve Bank [SARB], 2013). These low saving ratios will increase pressure on personal finances and are likely to be a burden on personal financial well-being. The household debt to disposable income ratio of Canada was 161.8\% in the first quarter of 2013 (Statistics Canada, 2013) and New Zealand's was 146.2\% (Reserve Bank of New Zealand [RBNZ], 2013). South Africa's household debt to disposable income ratio for the second quarter in 2013 was $75.8 \%$ (SARB, 2013). Generally, a household debt to income ratio above $40 \%$ is associated with financial difficulty (Bank of America, 2011; Xiao \& Yao, 2011). Considering that the average household's debt to income ratio exceeds $40 \%$, it becomes clear that households are highly over-indebted. The consumerism-driven economy and credit card system tempt young adults to incur debt, which has been found to have a negative impact on young adults' financial well-being (Shim, Xiao, Barber, \& Lyons, 2009). Shim and Xiao et al. (2009) found that high debt is also associated with low financial satisfaction. Low financial satisfaction, in turn, was found to be related to low overall life satisfaction (Shim, Xiao et al., 2009).

From the above discussion, it can be construed that most people have high financial stress levels considering the numerous pressures on personal finances and the fact that many people's financial situation is unfavourable. Joo (1998) and Garman et al. (2007) established that a person's financial stress is associated with his/her financial well-being. Considering that financial well-being is associated with financial stress, it is expected that increasing pressures on personal finance will increase the level of financial stress and pose a threat to personal financial well-being and eventually overall well-being. Because financial well-being is threatened by common financial pressures, will this lowered financial well-being have an effect on a person's performance at work?

Employees with high financial stress and low financial well-being tend to be more frequently absent from work (Kim \& Garman, 2003). It has also been found that worker productivity and workers' financial well-being are positively related (Joo, 1998; Joo \& Garman, 1998). Employees' financial concerns impede their work and they use time at work to attend to financial issues (Bagwell, 2000; Kim, 2000; Kim, Sorhaindo, \& Garman, 2006; Garman et al., 2005; Kim \& Garman, 2004). Kim and Garman (2003) also found financial stress to be negatively related to organisational commitment, while Kim (1999) found financial well-being to be positively related to organisational commitment. The above-mentioned references show that a lack of financial well-being can have a negative impact on employees' work performance. The need for more research regarding financial stress and its impact on the workplace has been expressed by various researchers (Kim \& Garman, 2003; Bagwell, 2000). Therefore, the problem investigated in this study is the fact that further research in this area is necessary in order to understand the relationship between factors affecting personal financial well-being in order to convince management that improving employees' financial well-being will add value to the company (Kim \& Garman, 2003; Bagwell, 2000). This will also assist in identifying the most suitable and effective interventions to incorporate as part of an employee wellness plan. If employee financial wellness is effectively addressed, it will contribute to the financial wellness of the larger population.

To fill this knowledge gap, the purpose of the study is to establish and measure the relationship of the subjective measures financial efficacy and satisfaction with remuneration, identified from the literature, with personal financial well-being. The research fulfils this purpose by means of a large sample survey from which the data was used to measure and explain the relationships. The current study therefore contributes to research regarding the return on investment of intervention programmes aimed at increasing personal financial well-being.

The remainder of the paper is organised as follows: The next section provides a background to the study, followed by a section that sets out the detailed objectives and hypotheses, then a section to explain the research methodology. This is followed by a section that reveals the findings and the study is summarised, discussed and concluded in the final section. 


\section{BACKGROUND}

\section{Conceptual Scope And Definition}

Based on research by Porter (1990), financial well-being can be defined as objective and subjective aspects of a person's financial situation evaluated against standards of comparison to form a person's opinion of his/her financial situation. "Financial well-being is about effectively managing your economic life. People with high financial well-being manage their personal finances well and spend their money wisely" (Rath, Harter, \& Harter, 2010). For the purposes of this study, financial well-being is defined as objective and subjective aspects that contribute to a person's assessment of his/her current financial situation. Financial efficacy is defined as a person's perceived capability to control his/her personal finances (Lapp, 2010; Postmus, 2011). Fox and Bartholomae (2008) defined financial efficacy as "knowledge and ability to influence and control one's financial matters". In this study, financial efficacy is interpreted as a person's satisfaction with/confidence in his/her level of financial knowledge and his/her ability to meet financial objectives. Satisfaction with remuneration incorporates satisfaction with level of remuneration, remuneration structure and raises (Kim, 2000). A person's satisfaction with remuneration refers to the difference between the amount a person believes he/she should receive and the amount he/she believes he/she did receive (Lawler, 1971). Therefore, the following understanding of the term is used in the study; satisfaction with remuneration is a person's attitude towards the adequacy of his/her remuneration package.

\section{Literature Review}

Above and beyond the fact that increasing the financial well-being of employees needs to add value to the business, management can meet their moral obligation by looking after the well-being of their employees. Drawing and retaining quality employees are very important for the success of an entity. As a result, ensuring employees' well-being should be one of the entity's non-financial objectives (Woods, 2002; Ogilvie, 2008). Personal finances are one of the aspects that have been found to affect overall well-being (Kahneman \& Deaton, 2010; Ogilvie, 2008; Rath et al., 2010; Charles, Danziger, Pounder, \& Schoeni, 2006; Mills, Grasmick, Morgan, \& Wenk, 1992; Pittman \& Lloyd, 1988). With increasing financial pressures threatening financial well-being, this will affect a person's overall well-being. In order to meet their non-financial objectives, management can aim to improve financial wellbeing in an attempt to improve the overall well-being of employees.

Considering that employees who are financially more sound's personal finances have a smaller interference at work, it seems that employees who are more financially sound will benefit an organisation. As a result, management should consider ways in which they can increase employees' financial well-being in order to ensure less interference at work. This will therefore not only benefit the employee, but also the organisation, resulting in a win-win situation. Garman et al. (2005) have suggested the following possible ways to increase financial well-being; to evaluate and improve spending behaviours, increase income, manage debt more effectively, and seek financial education in the workplace. Two methods were identified for further analysis and discussion in this study. Firstly, the level of remuneration can be increased (Garman et al., 2005). Other researchers have also included income level as one of the objective measures of financial well-being (Kahneman \& Deaton, 2010; Joo, 1998; Leach, Hayhoe, \& Turner, 1999; Hayhoe \& Wilhelm, 1998; Wilhelm, Varcoe, \& Fridrich, 1993). Since the measurement of financial well-being includes the remuneration level, it should theoretically increase financial well-being when the level of remuneration is raised. Secondly, researchers have suggested that employers should provide employees with financial education programmes (which may include ways to manage debt better and improve spending behaviours) in order to improve personal financial well-being (Bagwell, 2000; Kim, 2000; Kim et al., 2006; Kim \& Garman, 2003; Bailey, Woodiel, Turner, \& Young, 1998; Kim \& Garman, 2004; Kim, 2008; Garman, Kim, Kratzer, Brunson, \& Joo, 1999; Prawitz \& Garman, 2009; O'Neill, Xiao, Sorhaindo, \& Graman, 2005; Hira \& Loibl, 2005; Garman et al., 2005; Taft, Hosein, \& Mehrizi, 2013). A summary of the literature regarding the methods follows.

\section{Increase In Remuneration Level}

An increase in remuneration may well be the easiest alternative. The first problem, however, with increasing remuneration is that a business has limited resources at its disposal. A remuneration increase can only be sustained up to a certain point. Secondly, it is uncertain whether employees' financial well-being will substantially 
increase after an increase in remuneration level. Some researchers found that an increase in remuneration only leads to a small increase in well-being (Frey \& Stutzer, 2000; Diener, Sandvik, Seidlitz, \& Diener, 1993; Oswald, 1997; Easterlin, 1974; Binder \& Coad, 2011). Others have found that an increase in remuneration does not increase subjective well-being; as remuneration increases, the desire for worldly possessions also increases, leaving subjective well-being at the same level (Diener, 2000; Easterlin, 1995; Easterlin, 2001). Subjective well-being can be defined as a person's overall happiness with life (Binder \& Coad, 2011). It has also been stated that an increase in remuneration increases a person's desire and, therefore, if there is any increase in well-being, it will be only temporary (Diener, Suh, Lucas, \& Smith, 1999). Low financial well-being is also not a condition that exists only among employees with a low level of remuneration, it exists across all remuneration levels (Garman et al., 2005; D'Acci, 2010). It seems that the actual level of remuneration is not the only factor of remuneration contributing to a person's financial well-being.

Bearing in mind that an increase in remuneration will at most have a small impact on well-being, other possibilities need to be considered in order to achieve a sustainable increase in employees' financial well-being. Garman et al. (2004) and Porter (1990) stated that objective measures (factual measures, such as income, which are not influenced by one's belief) of financial well-being are only part of the financial well-being story. Garman et al. (2004) observed that people in the same financial situation showed different levels of distress and concluded that one's perception of financial issues is a key component of personal financial well-being. Strumpel (1976), Joo (1998) and Porter (1990) proposed the inclusion of satisfaction with remuneration as one of the subjective measures of financial well-being. Considering that subjective measures of financial well-being are just as important as objective measures, will an increase in satisfaction with remuneration, rather than an increase in the remuneration level, increase financial well-being? If management focuses on employees' satisfaction with remuneration (subjective) instead of actual remuneration (objective), will this improve financial well-being?

Literature on satisfaction with remuneration has shown that satisfaction with remuneration is a concept with multiple components (Kim, 1999; Heneman \& Schwab, 1985; Ash, Bretz, \& Dreher, 1990). Lawler (1971) defined satisfaction with remuneration as the difference between the amount a person believes he/she should receive and the amount he/she believes he/she did receive. Measurements of satisfaction with remuneration include satisfaction with the pay system administration (Dyer \& Theriault, 1976; Weiner, 1980; Ash et al., 1990; Kim, Mone, \& Kim, 2008), income level increase (Spector, 1997; Prawitz \& Garman, 2009; Kim, 2000, Ash et al., 1990), benefits (Heneman \& Schwab, 1985; Kim et al., 2008), remuneration structure (Kim, 2000), belief that pay-forperformance is reasonable (Spector, 1997; Prawitz \& Garman, 2009) and satisfaction with the level of remuneration (Ash et al., 1990; Kim et al., 2008; Kim, 2000). Because satisfaction with remuneration is a multi-dimensional construct, it is expected that satisfaction with remuneration can be influenced by various aspects. Previous research regarding the relationship between financial well-being and remuneration satisfaction found that financial wellbeing is positively related to satisfaction with remuneration (Kim, 2000). Kim and Garman (2004) also found significant negative correlations between employees' financial stress and satisfaction with remuneration. Kim (2000) expressed the need for more research on the relationship between remuneration satisfaction and financial well-being.

This study will conduct further research on the relationship between satisfaction with remuneration and financial well-being, using a demographic group from a developing country (i.e. South Africa) and a larger number of participants when compared to previous studies. The study will also, for the first time, quantify the relationship within the sample of participants.

\section{Financial Education}

Considering that financial education has been identified in research as a factor that could potentially benefit financial well-being, what are the advantages of more financially literate individuals? An increase in financial literacy has been found to decrease financial stress (Calamato, 2010; Steen \& MacKenzie, 2013) and increase financial well-being (Garman et al., 1999; Holland, Goodman, \& Stich, 2008, Kumaran, 2013). In addition, research has also shown that financial literacy increases a person's financial efficacy (Fox \& Bartholomae, 2008; Lapp, 2010; Postmus, 2011). Postmus (2011) and Shim, Barber, Card, Xiao, and Serido (2009) found that financial literacy alone is not enough to ensure control over personal finances; financial efficacy is equally as important. 
Lapp's (2010) finding that higher financial efficacy predicts fewer financial problems (i.e. more control over personal finances) supported this notion. Upon further inspection of the efficacy concept, it was noted that higher self-efficacy motivates people to try harder to master challenges (Bandura, 1977). Will increased financial efficacy enable a person to overcome financial difficulty more easily and effectively increase his/her financial well-being?

Some researchers have indirectly studied the relationship between financial efficacy and financial wellbeing. Xiao, Tang, Serido, and Shim (2011) divided perceived behavioural control into financial efficacy and controllability. Perceived behavioural control (which includes financial efficacy) was found to have a positive relationship with good financial behaviours (Shim, Barber et al., 2009; Xiao et al., 2011; Shim, Xiao et al., 2009; Staten \& Johnson, 2010). Good financial behaviour, in turn, was found to have positive relationships with financial satisfaction (Staten \& Johnson, 2010) and an aversion to debt (Shim, Xiao et al., 2009). Debt was one of the objective indicators used by Shim and Xiao et al. (2009) in order to determine the level of financial well-being. Therefore, financial efficacy (as part of overall perceived behavioural control) was found to indirectly have a positive relationship with financial satisfaction and financial well-being. Perceived behavioural control was also found to have a positive relationship with financial satisfaction (Shim, Barber et al., 2009; Shim, Xiao et al., 2009) and ability to cope with financial strain (Shim, Xiao et al., 2009). Some researchers use financial satisfaction as a measure of financial well-being (Joo, 1998; Shim, Xiao et al., 2009; Wilhelm et al., 1993). Shim and Xiao et al. (2009) used ability to cope with financial strain as a measure of financial well-being. One can conclude that financial efficacy (as part of perceived behavioural control) has a positive relationship with financial well-being measurement instruments.

Financial efficacy is influenced by a person's financial literacy and financial ability (Fox \& Bartholomae, 2008); therefore, will increased financial efficacy (due to an increase in financial literacy) lead to increased financial well-being? Further research into the direct relationship between financial well-being and financial efficacy will be conducted in the current study. The study will consider whether such relationships exist for the South African demographic profile described in the research methodology section.

\section{OBJECTIVES AND HYPOTHESES}

The main objective of this study is to establish and measure the effect that the subjective measures financial efficacy and satisfaction with remuneration have on personal financial well-being. Personal financial well-being influences a person's overall well-being (Ogilvie, 2008; Rath et al., 2010; Charles et al., 2006; Mills et al., 1992; Pittman \& Lloyd, 1988), which, in turn, influences a person's work (Kim \& Garman, 2003; Joo, 1998; Joo \& Garman, 1998; Bagwell, 2000; Kim, 2000; Kim et al., 2006; Garman et al., 2005; Kim \& Garman, 2004). If one can determine which factors influence a person's financial well-being and to what extent those factors influence financial well-being, constructive interventions can be designed to improve employees' financial well-being and work outcomes. Therefore, this research focuses on whether there is a relationship between financial efficacy, satisfaction with remuneration and personal financial well-being and exactly what the relationship is. In line with the objectives, the following hypotheses (as depicted in Figure 1) are tested in the study.

The hypotheses are graphically illustrated in Figure 1. 


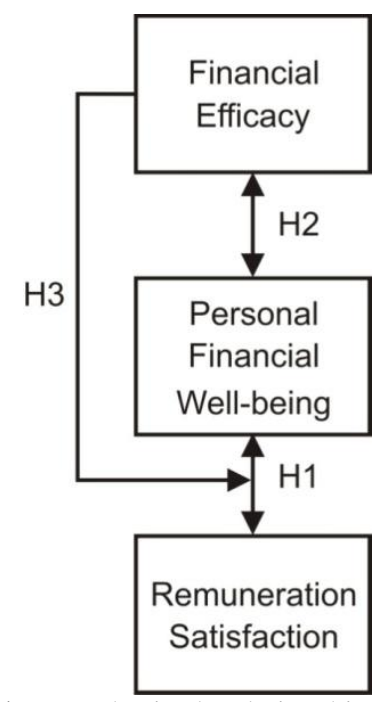

Figure 1: Hypothesised Relationship Between Variables

H1: There is a relationship between satisfaction with remuneration and personal financial well-being.

H2: There is a relationship between personal financial well-being and personal financial efficacy.

H3: Personal financial efficacy moderates the relationship between satisfaction with remuneration and personal financial well-being.

\section{RESEARCH METHODOLOGY}

This research study was conducted in the positivism paradigm. Statistical analyses (scientific methodologies) were used in this research in order to obtain an understanding of social and psychological concepts (The Open University, 2011). Experimental science has been adopted by positivists in order to use statistical methods of analysis on quantitative data to measure social occurrences and conclude on relationships found between variables (The Open University, 2011).

A quantitative, non-experimental cross-sectional design was applied in the study. The empirical research was based on existing data supplied by Afriforte (Pty) Ltd (Afriforte).

\section{Sampling}

The data was collected by Afriforte by means of the South African Employee Health and Wellness Survey (SAEHWS) (De Beer, Rothmann Jr., \& Pienaar, 2012; Rothmann \& Rothmann, 2007) on a secure website. Respondents were provided with a detailed description of the purpose of the study and were assured of the confidentiality of their responses prior to completing the questionnaire. Informed consent was provided by the respondents and it took them between twenty and thirty minutes to complete the questionnaire. Participation in the survey was voluntary. Permission was also granted by the management of each organisation to conduct the research and to use the data anonymously for research purposes. A sample of 13000 persons were invited to participate in the research project of which 9057 employees voluntarily participated (70\% up-take to the survey).

\section{Survey Validity}

The survey questions must be aligned with the objective of the research in order for the outcome to be meaningful (Taylor-Powell \& Hermann, 2000). Proper planning was conducted and the questionnaire was developed to examine the main and secondary objectives of the research study. As managerial consent and information regarding the purpose of the questionnaire were provided beforehand, employees were aware of the survey's relevance and importance. To ensure that participants answer the questions thoroughly and remain focused, a standardised sliding-scale questionnaire was used, making it possible to provide their own perspective within the context of the questions. 


\section{Measuring Instruments}

The three measuring instrument categories used in this analysis of the survey data are financial efficacy, satisfaction with remuneration and financial well-being. The questionnaire was a four-point scale marked from "Strongly Disagree" to "Strongly Agree". The following are examples of questions asked in order to measure the participants' level of financial well-being, financial efficacy and remuneration satisfaction:

- $\quad$ Financial efficacy: "I feel that I have the necessary skills to manage my finances."

- $\quad$ Satisfaction with remuneration: "I am paid enough for the work that I do."

- $\quad$ Financial well-being: "I am prepared for unexpected expenses that might occur during the month."

Factor scores were created in a confirmatory fashion, i.e. the items representing the factors were grouped together. The alpha coefficients for all of the constructs were acceptable: $\alpha \geq 0.70$.

\section{Statistical Analysis}

SPSS was used to perform statistical analysis. SPSS software is used for the statistical analysis of data and hypothesis testing (International Business Machines [IBM], 2013). Descriptive statistics were used to determine how the data was distributed. A confirmatory factor analysis was used as the survey was based on previous research findings and it was already known which items load onto which factors (De Beer, Rothmann Jr., \& Pienaar, 2012; Rothmann \& Rothmann, 2007). Pearson product-moment correlation coefficients were calculated to establish the relationship between variables (hypotheses 1 and 2). For hypothesis 3, multiple regression analysis was used to test the hypothesised moderating effect.

\section{ANALYSIS OF RESULTS}

The results are presented as the profile of the participants, descriptive statistics of the three measures and hypotheses testing.

\section{Profile Of Participants}

In total, 9057 employees ( $80.9 \%$ male and $19.1 \%$ female) of whom $19.9 \%$ were single, $0.8 \%$ engaged, $73.9 \%$ married, $4.8 \%$ divorced and $0.7 \%$ were a widow or widower participated. Table 1 provides further details about the participants' characteristics. The sample consisted of employees from different sectors in South Africa. The majority (56.7\%) of respondents were employed in the mining industry and $30.7 \%$ of the respondents are employed by the manufacturing industry. The remaining $12.6 \%$ of respondents are from the academic, call centres, engineering, government and other industries. Of all the participants, $23.8 \%$ had a three-year or higher degree/diploma, the remainder of the participants $(76.2 \%)$ had a grade 12 education or lower. 
Table 1: Characteristics Of The Participants ( $\mathrm{n}=9$ 057)

\begin{tabular}{llcc}
\hline \multicolumn{1}{c}{ Item } & \multicolumn{1}{c}{ Category } & Frequency & Percentage \\
\hline Sector & Academic & 304 & 3.4 \\
& Call centres & 35 & 0.4 \\
& Engineering & 277 & 3.1 \\
& Financial & 126 & 1.4 \\
& Government & 226 & 30.7 \\
Manufacturing & 2783 & 56.7 \\
& Mining & 5137 & 1.9 \\
\hline Other & Grade 8 & 169 & 19.1 \\
& Grade 9 & 1731 & 0.9 \\
& Grade 10 & 82 & 5.1 \\
& Grade 11 & 463 & 2.2 \\
& Grade 12 & 195 & 48.9 \\
& 3-year degree/diploma & 4432 & 13.4 \\
& 4-year degree/diploma & 1215 & 5.8 \\
& 5- to 7-year degree & 527 & 1.0 \\
& Master's degree & 93 & 2.8 \\
\end{tabular}

\section{Descriptive Statistics Of The Three Measures}

The descriptive statistics of the three measuring instruments (Financial well-being, Remuneration satisfaction and Financial efficacy) are provided below in Table 2. Of the 9057 employees who participated in the survey, only 8414 of the participants answered the questions relating to these three measuring instruments.

Table 2: Descriptive Statistics Of Measuring Instruments ( $n=8414$ )

\begin{tabular}{ccccccc}
\hline Item* & Min & Max & $\boldsymbol{M}^{* *}$ & $\boldsymbol{S D}^{* * *}$ & Skewness & Kurtosis \\
\hline FWB & 6.00 & 24.00 & 13.96 & 3.83 & 0.15 & -0.34 \\
FE & 3.00 & 12.00 & 8.81 & 1.79 & -0.40 & 0.45 \\
SR & 3.00 & 12.00 & 6.02 & 2.57 & 0.61 & -0.49 \\
\hline
\end{tabular}

$* F W B=$ Financial well-being; $S R=$ Remuneration satisfaction $; F E=$ Financial efficacy

** $M=$ Mean

$* * * S D=$ Standard deviation

The average financial well-being score was $13.96(S D=3.83)$. Financial efficacy's mean was $8.81(S D=$ $1.79)$ and satisfaction with remuneration's mean was $6.02(S D=2.57)$. Data is considered to be roughly normally shaped when skewness and kurtosis values range from -1 to 1 (Huck, 2012). The table shows that the skewness and kurtosis of all three variables fall within this range; therefore, all three variables are considered to be normally distributed. Normally distributed data implies that most of the scores are equally distributed (Field, 2009). Determining the distribution of data is important as certain statistical analyses (for example, regression analysis) assume that the data is normally distributed (Field, 2009).

\section{Testing Hypotheses 1 And 2}

A Pearson product-moment correlation coefficient was calculated to determine whether a relationship exists between financial efficacy and financial well-being; as well as a relationship between satisfaction with remuneration and financial well-being. The correlation matrix summarises the findings in Table 3. 
Table 3: Pearson Correlation Coefficients

\begin{tabular}{lccc}
\hline Item & Financial Efficacy & Financial Well-Being & Remuneration Satisfaction \\
\hline Financial efficacy & 1.00 & & \\
Financial well-being & $.50 * *$ & 1.00 & \\
& .000 & $.63 * *$ & 1.00 \\
Remuneration satisfaction & $.29 *$ & .000 & \\
\hline
\end{tabular}

* Correlation is practically significant $0.24 \leq \mathrm{r} \geq 0.36$ (medium effect)

** Correlation is practically significant $r \geq 0.37$ (large effect)

The strength of the relationship was determined using Cohen's (1988) guidelines; small effect size when $0.1 \leq r \leq 0.23$, medium effect size for $0.24 \leq r \leq 0.36$ and large effect size for $r \geq 0.37$. The results shown in Table 3 support hypothesis 1 and a positive correlation was found between financial well-being and satisfaction with remuneration $(r=0.631, p=0.000$, two tails). The correlation is statistically significant $(p<0.05)$ as well as practically significant (large effect, $r \geq 0.37$ ). As a result, a person with high remuneration satisfaction will tend to have a higher level of financial well-being and vice versa. The results also supported hypothesis 2, showing that there is a positive correlation between financial efficacy and financial well-being ( $r=0.501, p=0.000$, two tails). This correlation was also found to be statistically significant $(p<0.05)$ and practically significant (large effect, $r \geq$ 0.37). Consequently, people with higher financial efficacy tend to be more financially sound and vice versa.

\section{Testing Hypothesis 3}

A multiple linear regression analysis was conducted in order to determine whether financial efficacy moderates the relationship between financial well-being and remuneration satisfaction. The moderator is the variable that influences the relationship between two other variables (Baron \& Kenny, 1986). The results are displayed in Table 4.

Table 4: Multiple Regression Analyses With Financial Well-Being As Dependant Variable

\begin{tabular}{|c|c|c|c|c|c|c|c|c|c|}
\hline \multirow[t]{2}{*}{ Model* } & \multicolumn{2}{|c|}{$\begin{array}{l}\text { Unstandardised } \\
\text { Coefficients }\end{array}$} & \multirow{2}{*}{$\begin{array}{c}\begin{array}{c}\text { Standardised } \\
\text { Coefficients }\end{array} \\
\text { B }\end{array}$} & \multirow[t]{2}{*}{$\mathbf{T}$} & \multirow[t]{2}{*}{ Sig. } & \multirow[t]{2}{*}{ F\# } & \multirow[t]{2}{*}{$\mathbf{R}^{2}$} & \multirow[t]{2}{*}{$\mathbf{R}_{\text {Adj }}^{2}$} & \multirow[t]{2}{*}{$\Delta \mathbf{R}^{2}$} \\
\hline & $\mathbf{B}$ & SE & & & & & & & \\
\hline 1 (constant) & 13.96 & .03 & & 476.64 & .000 & 4358.384 & .51 & .51 & .51 \\
\hline SR & .79 & .01 & .53 & 66.41 & .000 & & & & \\
\hline FE & .75 & .02 & .35 & 43.67 & .000 & & & & \\
\hline 2 (constant) & 13.83 & .03 & & 461.63 & .000 & 3075.614 & .52 & .52 & .01 \\
\hline SR & .76 & .01 & .51 & 63.24 & .000 & & & & \\
\hline $\mathrm{FE}$ & .78 & .02 & .36 & 45.85 & .000 & & & & \\
\hline SR $x$ FE & .10 & .01 & .12 & 15.84 & .000 & & & & \\
\hline
\end{tabular}

$* \mathrm{SR}=$ Satisfaction with remuneration; FE $=$ Financial efficacy

\# Statistically significant $(\mathrm{p}=.000)$

In Model 1, financial efficacy and satisfaction with remuneration were added as predictors of financial well-being. A significant regression equation was found $(\mathrm{F}(2,8411)=4358.384, p<.05)$ with an $R^{2}$ of .509 . This indicates that $50.9 \%$ of the variance in financial well-being can be explained by Model 1 . It also indicates that financial efficacy and remuneration satisfaction combined significantly predicts financial well-being. Both financial efficacy $(\beta=.349, p=.000)$ and remuneration satisfaction $(\beta=.53, p=.000)$ were found to have a significant impact on financial well-being.

The interaction between financial efficacy and satisfaction with remuneration was added as a predictor of financial well-being in order to construct Model 2. The addition of the interaction term resulted in a $\Delta \mathrm{R}^{2}$ of .014 , which supports the presence of a moderating effect $(\mathrm{F}(1,8410)=3075.614, p<.05)$. The interaction term accounted for an additional $1.4 \%$ of the variance in financial well-being. A significant moderating effect was found in the relationship between financial well-being and remuneration satisfaction $(\beta=.122, p=.000)$. The effect size was calculated based on the $f^{2}$ statistic that was proposed in Aiken and West (1991) and an effect size of 0.029 was calculated. According to Aguinis, Beaty, Boik, and Pierce (2005), an optimistic proposition for more realistic effect size categories is 0.005 (small), 0.01 (medium) and 0.025 for large. Therefore, one can argue that the moderating relationship found has a large practically significant effect. 
Figure 2 was plotted in order to clarify the moderating relationship found. The figure predicts financial well-being for three levels of financial efficacy and satisfaction with remuneration. The low level refers to $1 S D$ below mean of the particular predictor, whereas the high level refers to $1 S D$ above the mean and medium refers to the mean.

Figure 2: Interaction Effects Of Financial Efficacy And Satisfaction With Remuneration In Predicting Financial Well-Being

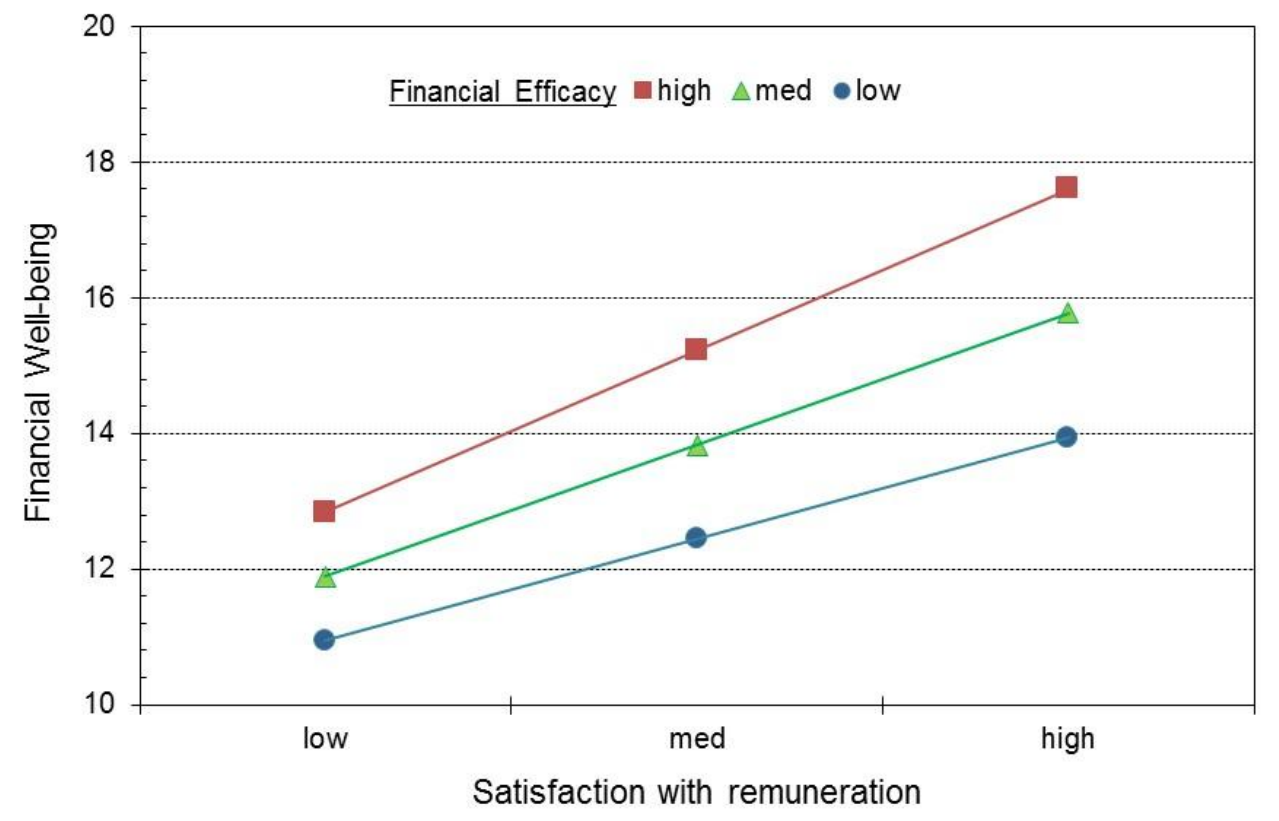

The higher the financial efficacy is, the steeper the slope will be. This indicates that an interactive effect does indeed exist. Hypothesis 3 is supported and it was found that financial efficacy moderates the relationship between financial well-being and remuneration satisfaction. The relationship between financial well-being and remuneration satisfaction is stronger in individuals with high financial efficacy (Figure 2).

\section{DISCUSSION}

This study investigated the effect that the subjective measures financial efficacy and satisfaction with remuneration have on personal financial well-being. In total, 9057 persons participated in the study. The study confirmed that a strong positive relationship exists between financial efficacy, satisfaction with remuneration and personal financial well-being. The correlations are statistically significant as well as practically significant for the sample. It was shown that $50.9 \%$ of the variance in financial well-being can be explained by financial efficacy and satisfaction with remuneration. This correlation between these two variables supports the inclusion of financial efficacy and satisfaction with remuneration as a measure of financial well-being (Strumpel, 1976; Joo, 1998; Porter, 1990).

These results also support Kim's $(1999 ; 2000)$ findings that remuneration satisfaction is positively related to financial well-being. The positive relationship found between financial well-being and satisfaction with remuneration indicates that if management increases employees' satisfaction with remuneration, and not necessarily only the level of remuneration, it is expected that their financial well-being will benefit. Satisfaction with remuneration is a concept with multiple components (Kim, 1999; Heneman \& Schwab, 1985; Ash et al., 1990); therefore, an improvement in one of the components is expected to have a positive effect in financial well-being. Consequently, above and beyond financial education, management can improve benefits (Heneman \& Schwab, 1985; Kim et al., 2008), improve pay system administration (Dyer \& Theriault, 1976; Weiner, 1980; Ash et al., 
1990; Kim et al., 2008), make employees feel valued or ensure that pay-for-performance is reasonable (Spector, 1997; Prawitz \& Garman, 2009) in an attempt to improve employees' financial well-being. This relationship between financial well-being and remuneration satisfaction suggests that an increase in the one concept is expected to result in an increase in the other concept.

From the literature, and as identified from own experience, management can therefore increase satisfaction with remuneration and eventually financial well-being by:

- $\quad$ Increasing the actual remuneration and benefits to employees. This may not be affordable on the long run as entities have limited resources. From the literature, it is also evident that addressing satisfaction with remuneration in this way only has a limited long-term effect.

- $\quad$ Addressing administrative issues of the pay-system and remuneration structure. This could include a smooth and efficient appointment and promotion process, leave-taking process and a reliable physical payment process. It could also include clear policies regarding promotion, salary structures and bonuses. This should be an easy matter to address and should not cost the entity too much.

- $\quad$ Addressing staff morale with regard to remuneration. This means that pay and bonuses are clearly linked to performance and the system is understood by employees and perceived to be fair and consistent. This may entail salary benchmarking and engaging frequently with staff. This matter is perhaps more difficult and it may be advisable to get in consultants in this regard.

- $\quad$ Increasing financial efficacy as discussed further on.

Financial well-being and financial efficacy were also found to have a strong positive relationship. Previous research indicated that financial efficacy (as part of the larger concept perceived behavioural control) had a positive relationship with financial well-being (Shim, Barber et al., 2009; Shim, Xiao et al., 2009). The current study shows that financial efficacy of its own accord tends to be associated with higher financial well-being. This finding also supports Lapp's (2010) finding that financial efficacy leads to fewer financial problems, which, in turn, affected financial well-being positively. Previous research has indicated that increased financial literacy is associated with increased financial efficacy (Fox \& Bartholomae, 2008; Lapp, 2010; Postmus, 2011). The relationship found between financial well-being and financial efficacy therefore indicates that increased financial literacy (from financial education) is expected to benefit financial well-being due to increased financial efficacy. Employers can therefore increase the financial efficacy and eventually personal financial well-being by:

- $\quad$ Offering financial literacy training as part of their employee wellness campaigns.

- $\quad$ Providing financial support and advice services through registered financial advisors.

It was additionally indicated that financial efficacy moderates the relationship between financial well-being and remuneration satisfaction. The interaction term accounted for an additional $1.4 \%$ of the variance in financial well-being, with a large practical significance.

This moderating relationship indicates that as a person's financial efficacy increases, so does the strength of the relationship between remuneration satisfaction and financial well-being. This is further evidence that increased financial efficacy can be beneficial to financial well-being through satisfaction with remuneration. Employees who can better manage their finances will experience better financial well-being and higher satisfaction with remuneration. This study strongly supports the notion that comprehensive financial education (that increases financial literacy) can be advantageous for financial well-being, due to the relationship found between financial efficacy and financial well-being as well as the moderating effect of financial efficacy through satisfaction with remuneration.

The results therefore support all three of the hypothesised relationships. Employees' financial well-being interferes with their work life by affecting absenteeism (Kim \& Garman, 2003), productivity (Joo, 1998; Joo \& Garman, 1998) and organisational commitment (Kim, 1999). The current study adds to research intended to convince management that intervention programmes aimed at improving financial well-being can add value to the company as well as benefit the employee personally. Two concepts were studied to determine their relationship 
with financial well-being. These two concepts (financial efficacy and satisfaction with remuneration) did indeed have a positive relationship with financial well-being. Therefore, intervention programmes addressing these two concepts are expected to result in a significant increase in a person's financial well-being, since $52.3 \%$ of the variance in financial well-being was explained by these variables.

\section{CONCLUSION}

The study aims to convince management that they can affect employees' financial well-being by positively influencing employees' satisfaction with remuneration and financial efficacy. A positive correlation was found between financial well-being and remuneration satisfaction.

The contribution of this study is threefold. Previous studies did not study the possibility of a direct relationship between financial efficacy and financial well-being, nor did they quantify the relationship between financial efficacy, satisfaction with remuneration and financial well-being. Furthermore, the samples used in previous research on financial efficacy and financial well-being were relatively small. This study investigated the relationship between financial well-being and financial efficacy with a significant sample of participants from the South African population and quantifies the relationship. The increasing pressures on personal finance pose a threat to financial well-being and interfere in the workplace. Management needs to be convinced that it is beneficial to the company to ensure the financial well-being of employees. The current study considered concepts that can be used by management to ultimately ensure that employees are financially sound. Furthermore, as indicated in the introduction, research has shown that a lack of financial well-being can have a negative impact on employees' work performance. Financial literacy training may therefore eventually benefit the entity as employees are more attentive due to less personal finance destruction.

The participants in the study completed the survey willingly; as a result, the sample used for the current study is a convenient sample (Salkind, 2007). One of the limitations of convenience samples is that the findings cannot be generalised past the population included in the study (Salkind, 2007). A limitation of the current study was that a convenient sample was used, which consisted of people employed in South Africa in certain industries. Therefore, any findings in this study cannot be generalised for the whole of South Africa, suggesting that it is possible that the same results will be obtained with a different population. The survey data was collected over a certain period of time and results cannot be generalised to past and future situations. Despite the limitations, the large number of participants and statistical correlations deducted add to the current body of knowledge on financial wellness. This is also the first study of this nature done within the South African (a developing country) context.

Further research is needed to quantify (in currency terms) the effect that financial well-being has on employees' work and whether any increase in financial well-being will ultimately reduce the cost of the company. This future research could be the final step in convincing management to ensure employees' financial well-being. Future research can also focus on specific practical ways that management can improve employees' financial wellbeing in line with the recommendations of the study.

\section{ACKNOWLEDGEMENTS}

The authors would like to acknowledge Afriforte Pty (Ltd) for their assistance in the data collection process. We also acknowledge the constructive comments provided by Ian Rothman and Leon de Beer. We would furthermore also like to thank the anonymous reviewers for their many helpful suggestions.

\section{AUTHOR INFORMATION}

Wilmie Vosloo is currently a trainee accountant in the third year of her SAICA articles contract. She is enrolled for a master's degree in financial management at the North-West University (South Africa). E-mail: vosloo.wilmie@gmail.com

Professor Jaco Fouché is currently professor in the School of Accounting Sciences at the North-West University (South Africa). He holds the Chartered Accountant (CA (SA)) designation and has taught extensively in the 
Chartered Accountancy programme. His current research focuses mainly on Accounting Education and Personal Financial Wellness. E-mail: jaco.fouche@nwu.ac.za (corresponding author)

Jaco Barnard is currently senior lecturer in the School of Accounting Sciences at the North-West University (South Africa). He holds the Chartered Accountant (CA (SA)) designation and has taught extensively in the Chartered Accountancy programme. His current research focuses mainly on Accounting Education and Personal Financial Wellness. E-mail: jaco.barnard@nwu.ac.za

\section{REFERENCES}

1. Aguinis, H., Beaty, J.C., Boik, R.J., \& Pierce, C.A. (2005). Effect size and power in assessing moderating effects of categorical variables using multiple regression: A 30-year review. Journal of Applied Psychology, 90(1), 94-107.

2. $\quad$ Aiken, L.S., \& West, S.G. (1991). Multiple regression: Testing and interpreting interactions. Newbury Park, CA: SAGE Publications.

3. Ash, R.A., Bretz, R.D., \& Dreher, G.F. (1990). Measurement and dimensionality of compensation satisfaction in law enforcement. Center for Advanced Human Resource Studies Working Paper Series, 9011. Retrieved from http://digitalcommons.ilr.cornell.edu/cgi/viewcontent.cgi?article=1375\&context=cahrswp\&seiredir=1\#search=\%22Measurement\%20Dimensionality\%20Compensation\%20Satisfaction\%20Law\%20Enf orcement $\% 22$

4. Bagwell, D.C. (2000). Work and personal financial outcomes of credit counseling clients (Doctoral thesis). Retrieved from http://scholar.lib.vt.edu/theses/available/etd-10082000-23210012/

5. Bailey, W.C., Woodiel, D.K., Turner, M.J., \& Young, J. (1998). The relationship of financial stress to overall stress and satisfaction. Personal Finances and Worker Productivity, 2(2):198-206.

6. Bandura, A. (1977). Self-efficacy: Toward a unifying theory of behavioral change. Psychological Review, 84(2), 191-215.

7. Bank of America. (2011). Keeping your debt load manageable. Retrieved from http://learn.bankofamerica.com/articles/managing-credit/keeping-your-debt-load-manageable.html

8. Baron, R.M., \& Kenny, D.A. (1986). The moderator-mediator variable distinction in social psychological research: Conceptual, strategic, and statistical considerations. Journal of Personality and Social Psychology, 51(6), 1173-1182.

9. Binder, M., \& Coad, A. (2011). From average Joe's happiness to miserable Jane and cheerful John: Using quantile regressions to analyze the full subjective well-being distribution. Journal of Economic Behavior \& Organization, 79(3), 275-290.

10. Calamato, M.P. (2010). Learning financial literacy in the family (Master's thesis). Retrieved from http://scholarworks.sjsu.edu/cgi/viewcontent.cgi?article=4846\&context=etd_theses

11. Charles, K.K., Danziger, S., Pounder, L., \& Schoeni, R.F. (2006, May). Consumption, Income and wellbeing among the mature population. Paper presented at the well-being of families and children as measured by consumption behaviour National Poverty Center conference, Washington, DC. Retrieved from http://www.npc.umich.edu/news/events/consumption06_agenda/pounder-charles-schoeni-danziger.pdf

12. Cohen, J. (1988). Statistical power analysis for the behavioral sciences (2nd ed.). Hillsdale, NJ: Lawrence Earlbaum Associates.

13. D'Acci, L. (2011). Measuring well-being and progress. Social Indicators Research, 104(1), 47-65.

14. De Beer, L., Rothmann, S., Jr, \& Pienaar, J. (2012). A confirmatory investigation of a job demandsresources model using a categorical estimator. Psychological Reports, 111(2), 528-544.

15. Diener, E. (2000). Subjective well-being - The science of happiness and a proposal for a national index. American Psychologist, 55(1), 34-43.

16. Diener, E., Sandvik, E., Seidlitz, L., \& Diener, M. (1993). The relationship between income and subjective well-being: Relative or absolute? Social indicators Research, 28(3), 195-223.

17. Diener, E., Suh, E.M., Lucas, R.E., \& Smith, H.L. (1999). Subjective well-being: Three decades of progress. Psychological Bulletin, 125(2), 276-302.

18. Dutkiewicz, C., Levin, S., \& Dukhi, A. (2007, November). The value of financial advice - It's not (just) about the cost. Paper presented at the Actuarial Society of South Africa convention, Johannesburg. 
Retrieved from http://www.actuarialsociety.org.za/Portals/2/Documents/Convention-

ValueOfFinancialAdvice-CD-SL-AD-2007.pdf

19. Dyer, L., \& Theriault, R. (1976). The determinants of pay satisfaction. Journal of Applied Psychology, 61(5), 596-604.

20. Easterlin, R.A. (1974). Does economic growth improve the human lot? Some empirical evidence. In P.A. David \& M.W. Reder (Eds.), Nations and households in economic growth: Essays in honor of Moses Abramovitz (pp. 89-125). New York, NY: Academic Press.

21. Easterlin, R.A. (1995). Will raising the incomes of all increase the happiness of all? Journal of Economic Behavior and Organization, 27(1), 35-47.

22. Easterlin, R.A. (2001). Income and Happiness: Towards a Unified Theory. The Economic Journal, 111(473), 465-484.

23. Fox, J.J., \& Bartholomae, S. (2008). Evaluation of the 2008 Women \& Money Program. Retrieved from http://www.osu.edu/search/index.php

24. Field, A. (2009). Discovering statistics using SPSS (3rd ed.). Thousand Oaks, CA: SAGE Publications.

25. Frey, B.S., \& Stutzer, A. (2000). Happiness, economy and institutions. The Economic Journal, 110(466), 918-938.

26. Garman, E.T., Junk, V.W., Kim, J., O’Neill, B.J., Prochaska-Cue, K., Prawitz, A.D., Lawrence, F.C., Yao, R., Weagley, R.O., Weisman, R.L., Carnathan, G., Schaus, S., Hutcheson, M.D., Mckinley, D.H., \& Brook, M.J. (2005). Financial distress among American workers (Final report: 30 million workers in America-one in four-are seriously financially distressed and dissatisfied causing negative impacts on individuals, families, and employers). Retrieved from http://www.personalfinancefoundation.org/features/feature3full.pdf

27. Garman, E.T., Kim, J., Kratzer, C.Y., Brunson, B.H., \& Joo, S. (1999). Workplace financial education improves personal financial wellness. Financial Counseling and Planning, 10(1), 79-88.

28. Garman, E.T., Leech, I.E., \& Grable, J.E. (1996). The negative impact of employee poor personal financial behaviors on employer. Financial Counseling and Planning, 7, 157-168.

29. Garman, E.T., Macdicken, B., Hunt, H., Shatwell, P., Haynes, G., Hanson, K.C., Hanson, E., Olson, P., \& Woehler, M.B. (2007). Progress in measuring changes in financial distress and financial well-being as a result of financial literacy programs. Consumer Interests Annual, 53. Retrieved from http://www.pfeef.org/research/fle/Progress-in-Measuring-Changes-in-Financial-Distress.doc

30. Garman, E.T., Sorhaindo, B., Kim, J., Xiao, J.J., Bailey, W., \& Prawitz, A.D. (2004). The development of the beta version of the In Charge financial distress scale. Consumer Interests Annual, 50, 134-144.

31. Hayhoe, C.R., \& Wilhelm, M.S. (1998). Modeling perceived economic well-being in a family setting: A gender perspective. Financial Counseling and Planning, 9(1), 21-34.

32. Heneman, H.G., \& Schwab, D.P. (1985). Pay satisfaction: Its multidimensional nature and measurement. International Journal of Psychology, 20(1), 129-141.

33. Hira, T.K., \& Loibl, C. (2005). Understanding the impact of employer-provided financial education on workplace satisfaction. Journal of Consumer Affairs, 39(1), 173-194.

34. Holland, J.H., Goodman, D., \& Stich, B. (2008). Defined contribution plans emerging in the public sector The manifestation of defined contribution and the effects of workplace financial literacy education. Review of Public Personnel Administration, 28(4), 367-384.

35. Huck, S.W. (2012). Reading statistics and research (6th ed.). Boston, MA: Pearson Education.

36. IBM (International Business Machines). (2013). Release Notes - IBM SPSS Statistics 22. Retrieved from http://www-01.ibm.com/support/docview.wss?uid=swg27038540

37. Joo, S. (1998). Personal financial wellness and worker job productivity (Doctoral thesis). Retrieved from http://scholar.lib.vt.edu/theses/available/etd-4198-155242/unrestricted/FRONTM_1.PDF

38. Joo, S., \& Garman, E.T. (1998). The potential effects of workplace financial education based on the relationship between personal financial wellness and worker job productivity. Personal Finances and Worker Productivity, 2(1), 163-173.

39. Kahneman, D., \& Deaton, A. (2010). High income improves evaluation of life but not emotional wellbeing. Proceedings of the National Academy of Science of the United States of America, 107(38), 1648916493.

40. Kim, J. (1999). Financial satisfaction, personal finance-work conflict, and work outcomes: Pay satisfaction, organizational commitment, and productivity. Paper presented at the Association for Financial 
Counseling and Planning Education Annual Conference, Scottsdale, AZ. Retrieved from http://www.pfeef.org/research/vte/Financial-Satisfaction-Personal-Finance-Work-Conflict-andOutcomes.doc

41. Kim, J. (2000). The effects of workplace financial education on personal finances and work outcomes (Doctoral thesis). Retrieved from http://scholar.lib.vt.edu/theses/available/etd-04212000-17150023/

42. Kim, J. (2008). Workplace financial education. In J.J. Xiao (Ed.), Handbook of consumer finance research (pp. 375-386). New York, NY: Springer.

43. Kim, J., \& Garman, E.T. (2003). Financial stress and absenteeism: An empirically derived research model. Financial Counseling and Planning, 14(1), 31-42.

44. Kim, J., \& Garman, E.T. (2004). Financial stress, pay satisfaction and workplace performance. Compensation \& Benefits Review, 36(1), 69-76.

45. Kim, J., Garman, E.T., \& Sorhaindo, B. (2003). Relationships among credit counseling clients' financial wellbeing, financial behaviors, financial stressor events, and health. Financial Counseling and Planning, 14(2), 75-87.

46. Kim, S., Mone, M.A., \& Kim, S. (2008). Relationships among self-efficacy, pay-for-performance perceptions, and pay satisfaction: A Korean examination. Human Performance, 21(2), 158-179.

47. Kim, J., Sorhaindo, B., \& Garman, E. (2006). Relationship between financial stress and workplace absenteeism of credit counseling clients. Journal of Family and Economic Issues, 27(3), 458-478.

48. Kumaran, S. (2013). Financial Literacy, Financial Education: A Road Map to Personal Financial WellBeing and Prosperity. International research journal of finance and economics, 108, 132-143.

49. Lapp, W.M. (2010). Behavioural models for driving prosperity for low income people: EARN's model of financial self-efficacy. Retrieved from

http://www.earn.org/static/uploads/files/EARN_Whitepaper_Behavioral_Models_Financial_Self_Efficacy_ Nov2010.pdf.pdf

50. Lawler, E.E. (1971). Pay and Organizational Effectiveness: A Psychological View. New York, NY: McGraw Hill.

51. Leach, L.J., Hayhoe, C.R., \& Turner, P.R. (1999). Factors affecting perceived economic well-being of college students: A gender perspective. Financial Counseling and Planning, 10(2), 11-24.

52. Louw, J., Fouché, J., \& Oberholzer, M. (2013). Financial literacy needs of South African third-year university students. International Business \& Economics Research Journal, 12(4), 439-450.

53. Mills, R.J., Grasmick, H.G., Morgan, C.S., \& Wenk, D. (1992). The effects of gender, family satisfaction, and economic strain on psychological well-being. Family Relations, 41(4), 440-445.

54. Molitor, N. (2010). Managing your stress in tough economic times. Retrieved from http://www.apa.org/helpcenter/economic-stress.aspx

55. Ogilvie, J. (2008). Financial strategy. Oxford: CIMA Publishing.

56. O'Neill, B., Xiao, J.J., Sorhaindo, B., \& Garman, E.T. (2005). Financially distressed consumers: Their financial practices, financial well-being, and health. Financial Counseling and Planning, 16(1), 73-87.

57. Oswald, A.J. (1997). Happiness and economic performance. The Economic Journal, 107(445), 1815-1831.

58. Pittman, J.F., \& Lloyd, S.A. (1988). Quality of family life, social support, and stress. Journal of Marriage and the Family, 50(1), 53-67.

59. Porter, N.M. (1990). Testing a model of financial well-being (Doctoral thesis). Available from ProQuest Dissertations and Theses database. (UMI No. 9028076).

60. Postmus, J.L. (2011). Understanding financial literacy with survivors of intimate partner violence. Retrieved from http://www.cfs.wisc.edu/briefs/Postmus2011_UnderstandingBrief.pdf

61. Prawitz, A.D., \& Garman, E.T. (2009). It's time to create a financially literate workforce to improve the bottom line. Benefits and Compensation Digest, 46(4), 11-14.

62. Rath, T., Harter, J., \& Harter, J.K. (2010). Well-being: The five essential elements. New York, NY: Gallup Press.

63. RBNZ (Reserve Bank of New Zealand). (2013). Key graphs - household debt. Retrieved from http://www.rbnz.govt.nz/statistics/key_graphs/household_debt/

64. Rothmann, S., \& Rothmann, J. C. (2007). The South African Employee Health and Wellness Survey (SAEHWS): User manual (4th ed.). Potchefstroom, ZA: Afriforte.

65. Salkind, N.J. (Ed.). (2007). Encyclopedia of measurement and statistics (Volume 1). Thousand Oaks, CA: SAGE Publications. 
66. SARB (South African Reserve Bank). (2013). Financial stability Review - September 2013. Retrieved from http://www.resbank.co.za/publications/detail-item-view/pages/publications.aspx?sarbweb=3b6aa07d-92ab441f-b7bf-bb7dfb1bedb4\&sarblist=21b5222e-7125-4e55-bb65-56fd3333371e\&sarbitem=5961

67. Shim, S., Barber, L.B., Card, N.A., Xiao, J.J., \& Serido, J. (2009). Financial socialization of first-year college students: The roles of parents, work, and education. Journal of Youth and Adolescence, 39(12), 1457-1470.

68. Shim, S., Xiao, J.J., Barber, B.L., \& Lyons, A.C. (2009). Pathways to life success: A conceptual model of financial well-being for young adults. Journal of Applied Developmental Psychology, 30(6), 708-723.

69. Spector, P.E. (1997). Job satisfaction: Application, assessment, causes, and consequences. Thousand Oaks, CA: SAGE Publications.

70. Staten, M.E., \& Johnson, C. (2010). Do inter-temporal preferences trump financial education courses in driving borrowing and payment behavior? Retrieved from http://tcainstitute.org/working_papers/Johnson\&Staten_Inter-temporal_Preferences.pdf

71. Statistics Canada. (2013). National balance sheet and financial flow accounts, first quarter 2013. Retrieved from http://www.statcan.gc.ca/daily-quotidien/130620/dq130620a-eng.pdf

72. Steen, A., \& MacKenzie, D. (2013). Financial Stress, Financial Literacy, Counselling and the Risk of Homelessness. Australasian Accounting Business and Finance Journal, 7(3), 31-48.

73. Strumpel, B., (Ed.). (1976). Economic means for human needs: Social indicators of well-being and discontent. Ann Arbor, MI: Institute for Social Research, University of Michigan.

74. Taft, M.K., Hosein, Z.Z., \& Mehrizi, S.M.T. (2013). The relation between financial literacy, financial wellbeing and financial concerns. International Journal of Business and Management, 8(11), 63-75.

75. Taylor-Powell, E., \& Hermann, C. (2000). Collecting evaluation data: Surveys. University of Wisconsin, Cooperative Extension. Retrieved from http://learningstore.uwex.edu/assets/pdfs/G3658-10.pdf

76. The Open University. (2011). Engaging with educational research - Two competing paradigms. Retrieved from http://www.open.edu/openlearn/education/educational-technology-and-practice/educationalpractice/engaging-educational-research/content-section-3.1

77. Trading Economics. (2013a). Germany personal savings. Retrieved from http://www.tradingeconomics.com/germany/personal-savings

78. Trading Economics. (2013b). United States personal savings rate. Retrieved from http://www.tradingeconomics.com/united-states/personal-savings

79. Weiner, N. (1980). Determinants and behavioral consequences of pay satisfaction: A comparison of two models. Personnel Psychology, 33(4), 741-757.

80. Weller, C.E., \& Logan, A.M. (2009). Measuring middle class economic security. Journal of Economic Issues, 43(2), 327-336.

81. Wilhelm, M.S., Varcoe, K., \& Fridrich, A.H. (1993). Financial satisfaction and assessment of financial progress: Importance of money attitudes. Financial Counseling and Planning, 4, 181-199.

82. Woods, M. (2002). Non-financial objectives. Retrieved from http://www.accountancy.com.pk/articles_students.asp?id=35

83. Xiao, J.J., Tang, C., Serido, J., \& Shim, S. (2011). Antecedents and consequences of risky credit behavior among college students: Application and extension of the theory of planned behavior. Journal of Public Policy and Marketing, 30(2), 239-245.

84. Xiao, J.J., \& Yao, R. (2011). Debt holding and burden by family structure in 1989-2007. Networks financial institute working paper, 2011-WP-04. Retrieved from http://indstate.edu/business/nfi/leadership/papers/2011-WP-04_Xiao.pdf 